\title{
MENTAL TOUGHNESS AND REJECTION SENSITIVITY IN ASSOCIATION OF WORK PERFORMANCE AMONG INTENSIVE CARE AND PSYCHIATRIC UNIT STAFF NURSES
}

\section{Samar Mabrook Abd elsalam Elnahrawy ${ }^{1}$, Marwa Samir Sorour ${ }^{2}$ \\ ${ }^{1}$ Lecturer of Psychiatric and Mental Health Nursing, Faculty of Nursing, Tanta University, ${ }^{2}$ Lecturer of Nursing Services Administration, Faculty of Nursing, Tanta University.}

\begin{abstract}
Background: Most nurses who are working with intensive care and psychiatric patients accept psychological talents and skills as mental toughness and rejection sensitivity that affect their work performance. Aim: To determine the association of mental toughness, rejection sensitivity, and work performance among staff nurses working at intensive care unit and psychiatric unit. Setting: This study was conducted at Medical Intensive Care Unit (MICU) as a group I and Inpatient's Unit of the Psychiatric as group II. Subjects: The study subjects were composed of simple random sample of nurses $(n=100)$ who working at the two settings. Tools: Three tools were used, Tool I: Mental Toughness Questionnaire, Tool II: Rejection Sensitivity Questionnaire, and Tool III: Nursing Work Performance Observational Checklist. Results: Majority (91.5\%) of group II obtained an average level of mental toughness and rejection sensitivity compared to $(54.7 \%$ and $81.1 \%$ ) of group I respectively. The total mean of nurses' responses about work performance all were at moderate level Mean \pm SD (2.699 \pm 10.930$)$ for group I compared to group II Mean \pm SD (2.368 \pm 9.081$)$. Conclusion: There were neither associations nor correlations between mental toughness, rejection sensitivity levels and work performance levels among staff nurses working at intensive care unit and psychiatric unit nursing groups. Recommendations: Conducting educational training program for nurses at two units about mental toughness and rejection sensitivity and maintaining the periodical orientation of nurses at two units about work performance dimensions.
\end{abstract}

Keywords: Intensive Care Unit, Mental Toughness, Psychiatric Unit, Rejection Sensitivity, Staff Nurses, Work Performance. 


\section{INTRODUCTION}

The nursing profession has been identified by a number of studies as a stressful occupation (Konstantinos, and Christian, 2008). Staff nurses work at mental health units and intensive care units (ICU) require an understanding of the situations, professional nursing experience due to their work density and rhythm by the diversity of technology, the constant responsibility of this job, which often does not finish when the work shift ends (Amy, Leanne ,and Amanda ,2018). So, all nurses should work as a team which leads to a lower level of nurses' work suffering from mental toughness that is greater than one can imagine (Chunxiao, Zhangd, Randhawab, Daniel, and Madiganf, 2020).

Mental toughness is defined as having the natural or developed psychological edge and managerial abilities to generally cope better by using many demands competition, training and lifestyle (Daniel, 2017). Mental toughness is a phrase often used to describe an athlete's ability to get through difficult circumstances or perform well under pressure (Gucciardi, Hanton, and Mallett, 2012). There are four main components of mental toughness: commitment/motivation, concentration/focus, control under pressure, and confidence/selfbelief (Gucciardi, Hanton, and Mallett, 2013).

Some people seem to have natural psychological and management talents in some of these components, these talents and skills can be learned to create greater mental toughness in anyone (Daniel, 2017). The natural psychological and management talents at commitment/ motivation include components such as when a nurse is setting difficult attainable goals and working harder than others to achieve these goals, is pushing good abilities to share an internal motivation to succeed and is bouncing back from performance setbacks (Gucciardi et al, 2012).

The natural psychological and management talents at concentration/focus contain components as a nurse is remaining focused on the task at hand, is not be distracted by events surrounding the performance of the task, is remaining in control despite unexpected or uncontrollable events, doesn't be distracted by personal circumstances or events, and is not also distracted by others (Cheung, and Li, 2019). While, nurses' talents at control under pressure may be able to cope effectively with adversity and stay calm under pressure, accept inevitable anxiety and enjoy it, make quick decisions, better work, and effort under pressure (Gerber et al., 2018). 
Also, the confidence/self- belief natural psychological and management nurses talents include some skills like having an unshakable belief to achieve goals, respecting unique qualities to succeed, and increasing positive beliefs to overcome obstacles (Haghighi, and Gerber 2019).

Mental toughness falls into one of these three categories: The first is thriving; in which mental toughness is quite strong to appear to work and handle challenges well and use some of the imaging techniques to improve even more ( $\mathrm{Li}$,Zhang , and Zhang ,2019). The second is surviving; it doesn't appear likely performing the best work very often to reach the highest goals, the brain will need to improve the mental skill areas where mental toughness continues to help them achieve greater success. The third is struggling; it appears to be in several of the four mental toughness areas in the brain. It uses some immediate guidance for following advice, and the given recommendation (Papageorgiou, Gianniou, Wilson, Moneta, Bilello, and Clough, 2019).

Acceptance and rejection are both extremely important events in an individual's life; both can rouse his/her emotionally and psychologically (Nafees, and Jahan, 2018). Rejection sensitivity may be considered as a defensive motivation system activated in interpersonal contexts, which biases individuals to willingly perceive and strongly react to the clues of rejection (Innamorati, Balsamo, Fairfield, and Fabbricatore, 2014).

Nursing rejection sensitivity reflects anxious expectations of rejection in general, rather than rejection based on a specific characteristic of nurses (DeBono, and Muraven, 2014). Nurses who anxiously expect to be rejected based on their feelings vulnerable at work situations in which they could be evaluated based on their performance whereas, rejection sensitivity operates across a variety of relationship contexts e.g. with other nurses, doctors, patients or even with strangers, friends and family members (Ayduk, Gyurak ,and Luerssen, 2008).

As ICU and psychiatric nurses must render their care to patients with respect, listen actively, gather information, analyze what has been said, and synthesize it in their assessments, the nurse's main goal is to achieve mutual agreement and concordance with the care seeker and avoid to be rejected from patients or other health care providers at work setting (Kouchaki, and Wareham, 2015). The three main feeling items for rejection sensitivity in nursing practice are: feeling trapped, feeling disrespected, and feeling invited (DeBono et al, 2014). 
First, feeling trapped occurs when nurses being obsessed with worry and hard- pressed by external circumstances give rise to a feeling of being trapped due to a lack of self -belief as well as a fear of making the wrong decisions about their health or their responsibility for patients (Lenton, Bruder, Slabu , and Sedikides, 2013). Second, feeling disrespected occurs when the nurses feel that they are not respected, as they have to struggle to be valued and avoid being refused, feeling despised and ignored, as well as feeling let down and abandoned (Newman, Bloom, and Knobe, 2014).

Third, feeling invited occurs when nurses perceived any serious work conversation and focused her/his feeling and responses to what others said even patients or other health care providers, which gave those nurses confirmed perception and feeling about others perception that reflects their work performance level (Leary ,Twenge , and Quinlivan, 2006) and (Wojciszke ,Abele, and Baryla, 2009).

Effective nursing care performance occurs when nurses can commit, motivate, concentrate, control his/her pressure, and have high self - confidence (Chunxiao et al, 2020). The main component of natural mental toughness is to develop nursing psychological and managerial performance to cope with different feelings of rejection sensitivity in nursing practice settings or different real - life situations (Gucciardi et al, 2013).

Nurses' work performance denotes how effective nurses achieve their responsibilities and duties that concern patient care (Gonzalez-Gil et al., 2020). The goal of work performance is to provide honest insights into how a nurse perceives her/his work and deals with other health care providers (Thulth, Sayej, 2015). It is a great tool for ensuring all nurses remain productive person and be able to meet all tasks and goals for the betterment of the health organization through effective personal development (Huston, and Marquis, 2013).

ICU and psychiatric nursing work performance can be measured based on main dimensions that include: work habits, staff relations, communication, record-keeping, attendance, and documentation (Nikpeyma, Saeedi, Azargashb, and Majd, 2014). These dimensions are related to the organizational entities involved in nursing care provision in relation to articulate goals and functions and the resulting outcomes (Morodiya, 2014).

Nursing evidence reveals that competent, motivated, and skilled staff nurses are a cornerstone for a better performance of health care organizations (Tesfaye, Hailu, and Nemera ,2015). One of the most crucial parts of nursing work performance is nurses' awareness. When a nurse is a work aware, she/he is conscious of her/his strengths and weaknesses and how others perceive her/him (Mahran, Saleh, and Taher, 2017). A higher level 
of nursing awareness means that a nurse is more likely to have a higher confidence level, to build strong relationships, and to make better decisions and better work (Kaleem, Jabeen, and Twana, 2013).

Work performance does not only benefit the nurses on an individual level, but it also helps their health organization development and has a direct impact on nurses' experience positive level of the stressful demanding environment in a term of empathetic communication with patients, their relatives, and other medical teams (Matsumoto , and Yoshioka ,2019).

\section{Significance of this study:}

Due to few studies that contribute to nursing mental toughness and rejection sensitivity with a level of work performance (Mahran et al., 2017). So, the current study aimed to determine the association between these variables as nursing work performance is the mirror of what a nurse has learned and what things or feelings about mental toughness and actions of rejection sensitivity can reflect positively on nursing work performance environment. Consequently, understanding such concepts in the context of the healthcare sector may in turn help for establishing new talents and skills among the staff nursing teams to improve the quality of health care (Tesfaye et al., 2015).

\section{AIM OF THE STUDY}

The study aimed to determine the association of mental toughness, rejection sensitivity, and work performance among staff nurses working at intensive care unit and psychiatric unit.

\section{Research question:}

- Are there associations of mental toughness, rejection sensitivity, and work performance among staff nurses working at intensive care unit and psychiatric unit?

\section{SUBJECTS AND METHOD}

\section{Study design}

Non-experimental descriptive correlational study design had been applied in the current research.

\section{Study setting:}

This study had been conducted at two different settings, at Medical Intensive Care Unit (MICU) of Tanta University Hospital affiliated to Higher Education Ministry as Group I (ICU nurses) and Inpatient's Unit of the Psychiatric and Mental Health Hospital affiliated to The General Secretariat of Mental Health as Group II of psychiatric nurses. The researchers 
selected MICU because staff nurses' socio-demographic characteristics at this unit were considered the nearest similar to psychiatrists nurses ones than other units of ICUs plus intensive care unit is the nearest similarity of workload stress to a psychiatric unit.

\section{Subjects:}

The study subjects were composed of simple random sample $(n=100)$ nurses. Group I $(n=53)$, Group II $(n=47)$ with a minimum one year of working experience in two studied group nurses that were chosen for the current study.

\section{Tools of data collection for study:}

Three tools were used to collect data for this study.

\section{Tool I: 4 Cs Mental Toughness.}

This tool included two parts:

Part I: Socio-demographic characteristics questionnaire: It was built by the researchers after reviewing the related literature. Socio-demographic data included nurses' age, gender, housing, marital status, years' of experience, level of education, and nurse-patient ratio.

\section{Part II: Mental Toughness Questionnaire}

4 Cs Mental Toughness Questionnaire 24- items were adapted by (Clough, Earle, Sewell, 2002), to assess nurses' levels for mental toughness. It includes four subscales; Control, Commitment, Challenge, and Confidence. Participants have indicated their level of the agreement through a five-point Likert-type scale anchored at $1=$ strongly disagree and $5=$ strongly agree.

\section{Scoring of mental toughness:}

The total score of mental toughness ranged from $(24-120)$, which is the sum of all nurses' responses. Scores from $(24-47)$ points are considered as "weak level", scores from (48- 71) are denoted as "average level", and scores from (72-120) are considered as "high level".

\section{Tool II: Rejection Sensitivity Questionnaire.}

The Rejection Sensitivity Questionnaire (RSQ) was developed by (Downey, Feldman, 1996) based on the 18 situations with selecting fixed-choice responses to each situation to assess rejection-anxiety and rejection expectations level for nurses, it rated on a 7-point scale 
ranging from very unconcerned (1) to very concerned (7). The high likelihood degree of this outcome denotes expectations of acceptance, and the low likelihood degree represents expectations of rejection.

\section{Scoring of rejection sensitivity:}

The total score of rejection sensitivity ranged from $(18-126)$, which is the sum of all nurses' responses. Scores from (18 - 53) points were considered as "weak level", scores from (54- 71) were denoted as "average level", and scores from (72-126) were considered as "high level".

Reflecting our adoption of an expectancy-value model of anxious expectations of rejection, computation of the RSQ scores was as follows: First, we obtained a rejection sensitivity score for each situation by evaluating the anticipated likelihood of rejection by the degree of concern over its occurrence. Specifically, we reversed the score on the expectancy of acceptance to index expectancy of rejection (expectancy of rejection $=7$ - expectancy of acceptance). We then multiplied the reversed score by the score for the degree of anxiety or concern. Second, we computed a total (cross-situational) rejection sensitivity score for each participant by summing the rejection sensitivity scores for each situation and dividing by 18 , the total number of situations.

\section{Tool III: Nursing Work Performance Observational Checklist.}

This tool was adapted from (Gonzalez-Gil et al, 2020) and (Thulth et al., 2015) to assess staff nurses work performance levels based on the general job description of each unit related to six dimensions subscales during their work time by utilizing an observational checklist included 24 items; four items for each subscale according to work habits, staff relations, attendance, communication, documentation, and record keeping dimensions. Each item is rated on two-point scale where $1=$ not done, $2=$ done.

A sample items for the work habits dimension based on the general job description of each unit were 'Nurse uniform and personal identification card is committed to, Nurse' work is done under health and safety practices". While for documentation, dimension were "Nurse documents the medical and nonmedical information correctly on the approved hospital forms, Nurse documents the information in a correct manner that facilitates the development of nursing care plan. Also, for staff relations dimension were "Nurse maintains effective relationships with her/his head nurse based on mutual respect, Nurse is collaborating with other colleagues in the completion of the collective works". Besides for attendance, dimension 
were 'Nurse' timeliness of attendance and leave is committed to, Nurse' work schedule is committed to and signed in".

\section{Scoring of work performance:}

The total score of work performance ranged from $(24-48)$ score points, which is the sum of all nurses' responses. It was considered as satisfactory work performance level $\geq 75 \%=(\geq 36$ score points) and unsatisfactory work performance level $<75 \%=(<36$ score points $)$.

\section{Method}

\section{1- Ethical Considerations was maintained:}

- Official permission was taken to conduct the study from Responsible Managers at Medical Intensive Care Unit of Tanta Hospital and Inpatient's Unit of the Psychiatric.

- Virtual and verbal consent was obtained from nurses after explaining the aim of the study.

- Privacy and confidentiality were assured. Nurses were reassured that the obtained information is confidential and used only for purpose of the study.

- Nurses' rights to withdraw from the study at any phase were respected.

2- Tools (I, II) of the current study were translated into the Arabic language.

3-Content Validity: A jury composed of five nursing field experts to assess the study of the three tools to examine the validity of tools for clearance, relevance, and appropriateness. The experts were; 3 assistant professors of the psychiatric nursing department, 2 assistant professors of the nursing services administration department, all of them are from the Faculty of Nursing, Tanta University. The experts' responses were represented in three points rating scale ranging from (3-1); $3=$ strongly relevant, $2=$ relevant, and $1=$ not relevant. The modifications are done accordingly. The values of content validity for tool I, tool II, tool III $(89.85 \%, 90.65 \%$, and $92.33 \%)$ respectively.

4-Testing Reliability: All tools (I, II, and III) were tested for reliability using the Cronbach Alpha Coefficient factor test and were found to be $(0.811,0.830$, and 0.910$)$ respectively.

5- A pilot study: It was carried out to verify the clarity, feasibility, and applicability of the study three tools and to identify obstacles that might be faced during data collection. The pilot study was conducted on $10 \%$ of the numbers of two group samples $(n=10)$ nurses outside the two study settings and excluded in the actual study subjects. After its implementation and consistency with its results, the mandatory modifications were done. 
6- Data Collection Phase: a- The researchers collected data of (the tool I and tool II) from two group's staff nurses by creating a special online Google Drive link and sent this online link to each group nurses, then statistically analysis done for all answers submission of both comparable groups nurses.

b- Tool III (Nursing Work Performance) was collected by the researchers used an observational checklist. The researchers collected data at two study settings using complete protection by wearing special PPE and using infection control precaution and all nurses were protected by wearing PPE. The data was collected over a period of four months from first August 2020 until the end of November 2020.

\section{Statistical analysis:}

The collected data was organized, tabulated, coded and statistically analyzed using the mean, standard deviation standard error, unpaired student t-test and the linear correlation coefficient, Analysis of variance [ANOVA] tests Paired t-test, and chi-square by SPSS V19 (Statistical Package for Social Studies) were created by IBM, Illinois, Chicago, USA (2016). The level of significance was adopted at $\mathrm{p}<0.005$.

\section{RESULTS:}

Table (1): Socio -demographic characteristics data among two studied group nurses. It was observed that the highest frequency of both studied group nurses (68\%) were aged 22-30years and a majority $(80 \%)$ of both groups were female. Most of the groups of the studied nurses (76\%) lived in rural residents. The majority of both studied group participants (80\%) were married. Over third of both group nurses (39\%) had an experience that ranged from 6-10 years. More than half of both group nurses (54\%) were graduated from a nursing technical institute. Nurse -patient ratio (46\%) at both group nurses was 1:3.

Table (2): A Comparison between G1 and G2 regarding total score levels of mental toughness. It was observed that the majority $(91.5 \%)$ of psychiatric nurses (group II) obtained an average level of mental toughness compared with over half $(54.7 \%)$ of ICU nurses (group I). There were statistically significant differences between all $4 \mathrm{cs}$ subscales items of total mental toughness $(\mathrm{p}=0.002)$.

Table (3): Comparison between G1 and G2 regarding total score levels of rejection sensitivity. The table revealed that there was statistically significant differences between the two studied group nurses' scores related to total rejection sensitivity items, as the majority (91.5\%) of a group (II) had average level for sensitivity rejection compared with $(81.1 \%)$ of a group (I). 
Table (4): Comparison between G1 and G2 regarding total mean score of work performance. It illustrated that the total mean of nurses responses about work performance for six subscales were at moderate level Mean \pm SD $(2.699 \pm 10.930)$ for group I compared with group II Mean \pm SD (2.368 \pm 9.081$)$ respectively with slight differences between the mean scores of all six dimensions of total work performance. Also, there weren't a statistically significant differences between all subscales except work habits and documentation subscales ( $p<0.001$ and $\mathrm{p}=0.024$ ) respectively.

Table (5): Correlation between total mental toughness, rejection sensitivity, and work performance among studied nurses. The table confirmed that there weren't a statistically significant correlations between total mental toughness, rejection sensitivity, and work performance among two comparable nursing groups $(\mathrm{p}=0.473, \mathrm{p}=0.342$, and $\mathrm{p}=0.089)$ respectively.

Table (1): Socio -demographic characteristics data among two studied group nurses

\begin{tabular}{|c|c|c|c|c|c|c|c|}
\hline \multirow{3}{*}{\multicolumn{2}{|c|}{ Demographic data }} & \multicolumn{6}{|c|}{ Comparative groups $(\mathrm{n}=\mathbf{1 0 0})$} \\
\hline & & \multicolumn{2}{|c|}{ (Group I) } & \multicolumn{2}{|c|}{ (Group II) } & \multicolumn{2}{|c|}{ Total } \\
\hline & & $\mathbf{N}$ & $\%$ & $\mathbf{N}$ & $\%$ & $\mathbf{N}$ & $\%$ \\
\hline \multirow{3}{*}{ Age } & $22-30$ & 42 & 79.2 & 26 & 55.3 & 68 & $\overline{68.0}$ \\
\hline & $31-40$ & 6 & 11.3 & 11 & 23.4 & 17 & 17.0 \\
\hline & 41-50 & 5 & 9.4 & 10 & 21.3 & 15 & 15.0 \\
\hline \multirow{2}{*}{ Gender } & Male & 8 & 15.1 & 12 & 25.5 & 20 & 20.0 \\
\hline & Female & 45 & 84.9 & 35 & 74.5 & 80 & 80.0 \\
\hline \multirow{2}{*}{ Housing } & Urban & 18 & 34.0 & 6 & 12.8 & 24 & 24.0 \\
\hline & Rural & 35 & 66.0 & 41 & 87.2 & 76 & 76.0 \\
\hline \multirow{4}{*}{$\begin{array}{l}\text { Marital } \\
\text { status }\end{array}$} & Single & 12 & 22.6 & 0 & 0.0 & 12 & 12.0 \\
\hline & Married & 37 & 69.8 & 43 & 91.5 & 80 & 80.0 \\
\hline & Divorced & 2 & 3.8 & 4 & 8.5 & 6 & 6.0 \\
\hline & Widower & 2 & 3.8 & 0 & 0.0 & 2 & 2.0 \\
\hline \multirow{3}{*}{$\begin{array}{l}\text { Years of } \\
\text { experience }\end{array}$} & $1-5$. & 26 & 49.1 & 7 & 14.9 & 33 & 33.0 \\
\hline & 6-10. & 14 & 26.4 & 25 & 53.2 & 39 & 39.0 \\
\hline & $>10$ & 13 & 24.5 & 15 & 31.9 & 28 & 28.0 \\
\hline \multirow{4}{*}{$\begin{array}{l}\text { Education } \\
\text { level }\end{array}$} & Nursing Diploma & 7 & 13.2 & 3 & 6.4 & 10 & 10.0 \\
\hline & $\begin{array}{l}\text { Nursing } \\
\text { Technical } \\
\text { Institute }\end{array}$ & 24 & 45.3 & 30 & 63.8 & 54 & 54.0 \\
\hline & BA & 17 & 32.1 & 14 & 29.8 & 31 & 31.0 \\
\hline & Postgraduate & 5 & 9.4 & 0 & 0.0 & 5 & 5.0 \\
\hline \multirow{4}{*}{$\begin{array}{l}\text { Nurse- } \\
\text { patient } \\
\text { ratio }\end{array}$} & $1: 1$ & 11 & 20.8 & 2 & 4.3 & 13 & 13.0 \\
\hline & $1: 2$ & 19 & 35.8 & 4 & 8.5 & 23 & 23.0 \\
\hline & $1: 3$ & 12 & 22.6 & 34 & 72.3 & 46 & 46.0 \\
\hline & 1:4 or more & 11 & 20.8 & 7 & 14.9 & 18 & 18.0 \\
\hline
\end{tabular}


Table (2): Comparison between G1 and G2 regarding total score levels of mental toughness

\begin{tabular}{|c|c|c|c|c|c|c|c|c|c|c|c|c|c|c|}
\hline \multirow{4}{*}{$\begin{array}{l}\text { Mental toughness } \\
\text { Cs Items }\end{array}$} & \multicolumn{12}{|c|}{ Levels of rejection sensitivity $(\mathrm{n}=\mathbf{1 0 0})$} & \multirow{4}{*}{$\begin{array}{l}\text { Chi- } \\
\text { square }\end{array}$} & \multirow{4}{*}{$\begin{array}{l}P \text { - } \\
\text { value }\end{array}$} \\
\hline & \multicolumn{6}{|c|}{ Group (I) } & \multicolumn{6}{|c|}{ Group (II) } & & \\
\hline & \multicolumn{2}{|c|}{ Weak } & \multicolumn{2}{|c|}{ Average } & \multicolumn{2}{|c|}{ High } & \multicolumn{2}{|c|}{ Weak } & \multicolumn{2}{|c|}{ Average } & \multicolumn{2}{|c|}{ High } & & \\
\hline & $\mathbf{N}$ & $\%$ & $\mathbf{N}$ & $\%$ & $\mathbf{N}$ & $\%$ & $\mathbf{N}$ & $\%$ & $\mathbf{N}$ & $\%$ & $\mathbf{N}$ & $\%$ & & \\
\hline $\begin{array}{l}\text { Commitment } \\
\text { /Motivation }\end{array}$ & 21 & 39.6 & 30 & 56.6 & 2 & 3.8 & 6 & 12.8 & 41 & 87.2 & 0 & 0.0 & 2.029 & $0.045 *$ \\
\hline Concentration & 19 & 35.8 & 31 & 58.5 & 3 & 5.7 & 3 & 6.4 & 43 & 91.5 & 1 & 2.1 & 3.422 & $0.001 *$ \\
\hline $\begin{array}{l}\text { Control under } \\
\text { Pressure }\end{array}$ & 16 & 30.2 & 37 & 69.8 & 0 & 0.0 & 4 & 8.5 & 40 & 85.1 & 3 & 6.4 & 2.968 & $0.004 *$ \\
\hline Confidence & 24 & 45.3 & 29 & 54.7 & 0 & 0.0 & 23 & 48.9 & 24 & 51.1 & 0 & 0.0 & 0.889 & 0.376 \\
\hline $\begin{array}{l}\text { Total mental } \\
\text { toughness }\end{array}$ & 24 & 45.3 & 29 & 54.7 & $\mathbf{0}$ & 0.0 & 4 & 8.5 & 43 & 91.5 & $\mathbf{0}$ & 0.0 & 3.222 & $0.002 *$ \\
\hline
\end{tabular}

* Significant at $\mathbf{P}<0.005$

Table (3): Comparison between G1 and G2 regarding total score levels of rejection sensitivity

\begin{tabular}{|c|c|c|c|c|c|c|c|c|c|c|c|c|c|c|}
\hline \multirow{3}{*}{$\begin{array}{l}\text { rejection } \\
\text { sensitivity }\end{array}$} & \multicolumn{12}{|c|}{ Levels of rejection sensitivity $(n=100)$} & \multirow{4}{*}{$\begin{array}{l}\text { Chi- } \\
\text { square }\end{array}$} & \multirow{4}{*}{$\begin{array}{l}\text { P- } \\
\text { value }\end{array}$} \\
\hline & \multicolumn{6}{|c|}{ Group (I) } & \multicolumn{6}{|c|}{ Group (II) } & & \\
\hline & & & Av & age & $\mathrm{Hi}$ & & & & & erag & & & & \\
\hline \multirow{2}{*}{$\begin{array}{l}\text { Total rejection } \\
\text { sensitivity }\end{array}$} & $\mathbf{N}$ & $\%$ & $\mathbf{N}$ & $\%$ & $\mathbf{N}$ & $\%$ & $\overline{\mathbf{N}}$ & $\%$ & $\mathbf{N}$ & $\%$ & $\mathbf{N}$ & $\%$ & & \\
\hline & 9 & 17.0 & 43 & 81.1 & 1 & 1.9 & $\mathbf{0}$ & $\mathbf{0 . 0}$ & 43 & 91.5 & 4 & 8.5 & 4.200 & $\begin{array}{l}<0.001 \\
*\end{array}$ \\
\hline
\end{tabular}

* Significant at $\mathbf{P}<0.005$ 
Table (4): Comparison between G1 and G2 regarding total mean score of work performance

\begin{tabular}{|c|c|c|c|c|c|c|}
\hline \multirow{4}{*}{$\begin{array}{l}\text { work } \\
\text { performance }\end{array}$} & \multicolumn{4}{|c|}{ Total mean score of work performance $(n=100)$} & \multirow{3}{*}{$\begin{array}{l}\text { Chi- } \\
\text { square }\end{array}$} & \multirow{3}{*}{ P-value } \\
\hline & \multicolumn{2}{|l|}{ (Group I) } & \multicolumn{2}{|l|}{ (Group II) } & & \\
\hline & Satisfactory & Unsatisfactory & Satisfactory & Unsatisfactory & & \\
\hline & \multicolumn{2}{|l|}{ Mean \pm SD } & \multicolumn{2}{|l|}{ Mean \pm SD } & & \\
\hline Work Habits & \multicolumn{2}{|l|}{$2.974 \pm 11.180$} & \multicolumn{2}{|l|}{$1.565 \pm 14.000$} & 5.934 & $<0.001^{*}$ \\
\hline Staff Relations & \multicolumn{2}{|l|}{$2.748 \pm 10.960$} & \multicolumn{2}{|l|}{$2.215 \pm 10.500$} & 0.922 & 0.359 \\
\hline Attendance & \multicolumn{2}{|l|}{$2.566 \pm 12.780$} & \multicolumn{2}{|l|}{$2.140 \pm 12.560$} & 0.466 & 0.643 \\
\hline Communication & \multicolumn{2}{|l|}{$2.135 \pm 12.180$} & \multicolumn{2}{|l|}{$2.069 \pm 11.380$} & 1.903 & 0.060 \\
\hline Documentation & \multicolumn{2}{|l|}{$3.032 \pm 8.780$} & \multicolumn{2}{|l|}{$2.527 \pm 10.060$} & 2.293 & $0.024 *$ \\
\hline $\begin{array}{l}\text { Record } \\
\text { Keeping }\end{array}$ & \multicolumn{2}{|l|}{$2.679 \pm 9.920$} & \multicolumn{2}{|l|}{$2.591 \pm 10.020$} & 0.190 & 0.850 \\
\hline $\begin{array}{l}\text { Total work } \\
\text { performance }\end{array}$ & \multicolumn{2}{|l|}{$2.699 \pm 10.930$} & \multicolumn{2}{|l|}{$2.368 \pm 9.081$} & 0.184 & 0.722 \\
\hline
\end{tabular}

* $\quad$ Significant at $\mathbf{P}<0.005$ / mean score level; (Low: 1.00 to 2.33), (Average: 2.34 to

3.66), (High: 3.67 to 5.00)

Table (5): Correlation between total mental toughness, rejection sensitivity and work performance among studied nurses

\begin{tabular}{|l|l|l|l|}
\hline \multicolumn{2}{|l|}{ Correlation $(\mathrm{n}=100)$} & $\begin{array}{l}\text { Total mental } \\
\text { toughness }\end{array}$ & Total rejection sensitivity \\
\hline $\begin{array}{l}\text { Total rejection } \\
\text { sensitivity }\end{array}$ & $\mathrm{R}$ & $\mathbf{0 . 0 7 3}$ & \\
\cline { 2 - 4 } & P-value & $\mathbf{0 . 4 7 3}$ & \\
\hline \multirow{2}{*}{ Total work performance } & $\mathrm{R}$ & $\mathbf{0 . 1 7 1}$ & $\mathbf{0 . 0 9 6}$ \\
\cline { 2 - 5 } & P-value & $\mathbf{0 . 0 8 9}$ & $\mathbf{0 . 3 4 2}$ \\
\hline
\end{tabular}

\section{DISCUSSION}

The purpose of the current study was to identify if there are associations between mental toughness, rejection sensitivity, and work performance among nurses working at medical intensive care unit and inpatient psychiatric unit. Regarding the study findings, there were neither associations nor correlations between those three variables among two group nurses.

These findings may be due to some nurses maybe had natural psychological and management talents and skills accepted or learned from their work environment to create 
greater mental toughness, which moderately affects their professional performance. Also, the majority of staff nurses at study sample of two groups were female and married, this means high tolerance level of pressure as the nature of a woman lifestyle and get through difficult circumstances as working harder than others to achieve these goals and pushing good abilities to share an internal motivation to succeed.

Moreover, staff nurses at the two different units used to deal with difficult, stressful, pressure environment work every day, which makes it usual for staff nurses to have the natural or developed psychological edge and managerial abilities to generally cope and perform better by using many demands competition, training, and lifestyle.

Conversely, a study developed by DeBono, and Muraven (2014) about rejection perceptions: feeling disrespected leads to greater aggression than feeling disliked, wasn't supported by the current research and confirmed there was a positive correlation between rejection sensitivity perception, and individual aggression feelings and care performance. In addition, Lin, Peter, and Clough (2017) was not in the line with the current study, assisting that the association between mental toughness (MT) and achievement may have significant consequences for expecting and heightening performance in various domains.

Also, Giles, Paul, and Daniel (2017) study about mental toughness and behavioral perseverance, not supported the current study results and revealed that mental toughness represents a salient positive psychological correlation of behavioral perseverance in an exceedingly discrete physical task that taxes the energy system in some but not all situations. When being fatigue, the effect of mental toughness is outweighed by more underlying fitness.

Concerning mental toughness, the current research founded that the majority of staff nurses had a moderate level of mental toughness at the psychological unit (group II) compared to over half of them at ICU (group I). These findings may be due to staff nurses of two groups worked at different work environment conditions with individuals differences to control under pressure and to cope moderately with adversity situations and to stay calm under pressure confirmed by most of them had moderate levels at the four main components of mental toughness: commitment/ motivation, concentration/focus, control under pressure, and confidence/self-belief.

But Georgi and Davenport (2019) investigated locating mental toughness in factor models of a personality, results indicated that people scoring high on mental toughness tended to endorse items related to push for results, having high energy levels, and an increased level 
of self-confidence. As well, emotional control, ambition, self-efficacy, creativity, and low anxiety arose because the strongest facet associates with mental toughness.

Regarding rejection sensitivity, the majority of staff nurses at the two units had a moderate level of sensitivity rejection. These results may be due to the fact that most of the staff nurses at two units had workload tasks and more nursing activities due to the nature of their work condition, which makes them experienced in coping with patients, other health care providers, and work friends or even with the patient - relatives about rejection sensitivity situations.

The studies of Gerber, and Wheeler (2009), Wojciszke et al. (2009), and Ozcelik et al. (2018) supported the study findings and revealed that social rejection leading people to experience increase social pain, create social exclusion, and different measures of feeling rejected. Also, it confirmed that social exclusion came from a high level of personal rejection which is a painful common experience in many people's work professional lives.

Regarding staff nurses' work performance, the study results illustrated that most of the staff nurses had a moderate mean score level of work performed at two comparable units. These findings may be due to the mixture of staff nurses experiences which included sixty percent of nurses at the psychiatric unit was nursing technician, compared to the third of them at two units had nursing bachelor degree (nursing specialist and nursing supervisor) that led to everyone in staff nurses perceived the items of current work performance differently.

Unfortunately, nurses facing many problems in their work environment, as nurses didn't get appropriate financial compensation and respect according to their duties, which are much more difficult as compared with doctors as they constantly deal with patients and spend unbearable long hours but are still not compensated as much as they deserve. Also, nurses counter to face the violent behavior of patients and their relatives in the hospital. Really, nurses experience high levels of the stressful demanding environment in time of empathetic communication with patients and their relatives and other medical teams.

Moreover, the result revealed that most staff nurses at group I compared to half of the staff nurses at group II were young 22-30 years, married, and female. Also, about half of nurses at ICU had work experience of 1-5 years compared to psychiatric nurses who had work experience of 6-10 years. All these factors led to the possibility that not each nurse was moderately oriented or motivated to know their current nurses' work performance items at two 
units, however, nurses needed to know these items and nursing manager have to assume their responsibility to clearly orient her nursing staff about the all performance dimensions items they must be reviewed.

Additionally, the nurse-patient ratio at psychiatric unit nurses was 1-3 than the third of ICU nurses was 1-2. All these reasons led to moderately work performance significantly at work habit and documentation dimensions, but led to nurses had high ability to cope with work pressure, work stress, mental toughness, and work sensitivity rejection. So, there was no statistically significant correlation between mental toughness and rejection sensitivity among psychiatric and intensive care unit nurses' on their work performance.

A study by Kundu (2015) about the performance evaluation of hospital employees, asserted that managers are responsible for creating conditions that motivate the nurses, eliminating performance problems, disseminate knowledge about work performance dimensions, standard, providing development opportunities, and reinforcing effective behavior. Also, Okoth (2016) supported the current results, and found that age is associated with experience and responsibility at work place; the longer nurses stick with their organization, the more they demonstrated an explicit motivation to make a difference in work performance. Abed-Hassan and EL Banan (2016) explore the relationship between quality of performance process and nurses' job satisfaction as perceived by staff nurses, supported the present finding and found that nurses should know the care performance standards clearly and have an idea on how to meet those standards and different nursing care work performance dimensions.

Certainly, the natural psychological and management skills and/or talents for staff nurses working at intensive care and psychiatric units cannot affect their work performance positively special to create greater ability on setting their own attainable goals and working harder to achieve these goals. An effective nursing manager has to conduct continued workshops about the importance of developing their staff work performance and their staff ability to commit, motivate, concentrate and control his/her pressure, for up-dating developing their staff nursing psychological and managerial performance level to cope with different feelings of rejection sensitivity within workplace setting and with different real-life situations. 


\section{CONCLUSION}

There were neither associations nor correlations between mental toughness, rejection sensitivity levels, and work performance levels among staff nurses working at intensive care unit and psychiatric unit.

\section{RECOMMENDATION}

Based on the findings of the present study the following recommendation was suggested:

1- Further researches should be applied to conduct an educational training programs for nurses at ICU and psychiatric about mental toughness and rejection sensitivity.

2- Applied educational training programs to address nurses on how to accept themselves and their hard work.

3- Continuous training programs and workshops about work performance dimensions for nurse managers and novice nurses at two units.

4- Nurse Managers should provide policies and programs that support the positive effect of performance on work development.

5- Maintaining periodical orientation of head nurses at two units about work performance dimensions

\section{REFERENCES:}

Abed-Hassan F, EL Banan S. (2016): The relationship between quality of performance appraisal process and nurses job satisfaction as perceived by staff nurses at a selected hospital. International Journal of Nursing Didatics. ; 6 (12): 15-21.

Amy J, Leanne M, Amanda C. (2018): Developing a minimum dataset for nursing team leader handover in the intensive care unit: A focus group study. Journal of Nurse Education Today. ; 31(1):47-9.

Ayduk O, Gyurak A, Luerssen A. (2008): Individual differences in the rejectionaggression link in the hot sauce paradigm: The case of rejection sensitivity. Journal of Experimental Social Psychology. ; 3 (10): 44, 77. 
Cheung P, Li C. (2019): Physical activity and mental toughness as antecedents of academic burnout among school students: A latent profile approach. International Journal of Environmental Research and Public Health. ; 16(11): 12.

Chunxiao L, Zhangd e, Randhawab A, Daniel J, Madiganf T. (2020): Emotional exhaustion and sleep problems in university students: Does mental toughness matter? Personality and Individual Differences journal. ; 4 (5): 163: 5.

Clough P, Earle K, Sewell D. (2002): Mental toughness: The concept and its measurement solutions in sport psychology. Journal of Social and Personality Psychology. ; 1 (2): $32-43$.

Daniel F. (2017): Mental toughness: progress and prospects. Science Direct Journal. ; 12 (14): 15 .

DeBono A, Muraven M. (2014): Rejection perceptions: Feeling disrespected leads to greater aggression than feeling disliked. Journal of Experimental Social Psychology. ; 3 (8): $52-5$.

Downey R, Feldman F. (1996): Implications of rejection sensitivity for intimate relationships. Journal of Social and Personality Psychology. ; 25 (7): 13, 70.

Georgi P, Davenport Y, Ryne A. (2019): Sherman locating mental toughness in factor models of personality. Personality and Individual Differences Journal. ; 1 (1): 4.

Gerber J, Wheeler L. (2009): On being rejected: A meta-analysis of experimental research on rejection. Perspectives on Psychological Science Journal. ; 4 (1): 4, 14.

Gerber M, Best S, Meerstetter F, Walter M, Ludyga S, Brand S, Gustafsson H. (2018): Effects of stress and mental toughness on burnout and depressive symptoms: A prospective study with young elite athletes. Journal of Science and Medicine in Sport; 21(12): 12.

Giles B, Paul R, Daniel F. (2017): Gucciardi. Mental toughness and behavioural perseverance: A conceptual replication and extension. Journal of Science and Medicine in Sport. ; 2 (5): 6 .

Gonzalez-Gil A, Parro-Moreno C, Oter-Quintana C, Gonzalez-Blazquez M, Martinez-Marcos M, Casillas-Santana A, Arlandis-Casanova C, Canalejas-Perez. (2020): 360-Degree evaluation: Towards a comprehensive, integrated assessment of performance on 
clinical placement in nursing degrees: A descriptive observational study. Nurse Education Today Journal. ; 3 (16): 93- 6 .

Gucciardi D, Hanton S, Mallett C. (2012): Progressing measurement in mental toughness: A case example of the mental toughness questionnaire 48. Sport Exercising Perform. Psychological Journal.; 1: 194,214.

Gucciardi D, Hanton S, Mallett C. (2013): Progressing measurement in mental toughness: A response to Clough, Earle, Perry, and Crust. Sport Exercise Perform Psychological Journal; 2:157-72.

Haghighi M, Gerber M. (2019): Does mental toughness buffer the relationship between perceived stress, depression, burnout, anxiety, and sleep?. International Journal of Stress Management; 26(3): 297,305.

Huston C, Marquis B. (2013): Performance appraisal leadership roles and management functions in nursing: Theory and application. North American Journal. ; 32 (14): 24.

Innamorati M, Balsamo M, Fairfield B, Fabbricatore M. (2014): Construct validity and reliability of the adult rejection sensitivity questionnaire: A comparison of three factor models. Depression Research and Treatment Journal. ; 1 (6): 2.

Kaleem M, Jabeen B, Twana M. (2013): Organizational justice in performance appraisal system: Impact on employee's satisfaction and work performance. International Journal of Management \& Organizational Studies; 2 (2):21.

Konstantinos N, Christian Q. (2008): Factors influence stress and job satisfaction of nurses working in psychiatric units: A research review. Health Science Journal; 2 (4): 183-95.

Kouchaki M, Wareham J. (2015): Excluded and behaving unethically: Social exclusion, physiological responses, and unethical behavior. Journal of Applied Psychology; 100(2): 547-56.

Kundu P. (2015): Performance evaluation of hospital employees through ongoing appraisal systems. International Journal of Thesis Projects and Dissertations; 3(2): 19-27. 
Leary R, Twenge M, Quinlivan E. (2006): Interpersonal rejection as a determinant of anger and aggression. Personality and Social Psychology Review Journal. ; 10: 111-32.

Lenton P, Bruder M, Slabu L, Sedikides C. (2013): How does 'being real" feel? The experience of state authenticity. Journal of Personality. ; 81(3), 276-89.

Li C, Zhang Q, Zhang L. (2019): Further examination of the psychometric properties of the mental toughness inventory: Evidence from Chinese athletes and university students. Journal of Current Psychology; 38(5), 1328-34.

Lin Y, Peter J, Clough Kostas A. (2017): Papageorgious individual differences in mental toughness associate with academic performance and income. Journal of Personality and Individual Differences. ; 9 (1): 2.

Mahran G, Saleh N, Taher A. (2017): Challenges and work crisis facing critical care nurses. Egyptian Nursing Journal; 14(3): 35.

Matsumoto Y, Yoshioka S., (2019): Factors influencing psychiatric nurses' job satisfaction levels: Focusing on their frequency of experiencing negative emotions toward patients and support at their workplaces. Yonago Acta Medical Journal. ; 62(4):293-304.

Morodiya S. (2014): Significance of performance appraisal system in improving the efficiency of nursing personnel toward patient care. Online International Interdisciplinary Research Journal; 1 (4): 303-7.

Nafees N, Jahan M. (2018): Fear of rejection: Scale development and validation. Indian Journal of Psychological Science; 10 (1): 70-6.

Newman E, Bloom P, Knobe J. (2014): Value judgments and the true self. Personality and Social Psychology Bulletin Journal; 40: 203 -16.

Nikpeyma N, Saeedi A, Azargashb E, Majd A. (2014): Problems of clinical nurse performance appraisal system: A qualitative study. Asian Nursing Research Journal; 8: 15-22.

Okoth O. (2016): Employee attitudes effect on human resource performance appraisal process in United Nations Office at Nairobi, Kenya. The International Journal of Business \& Management.; 4 (10): 37. 
Ozcelik H, Barsade S. (2018): No employee an island: Workplace loneliness and job performance. Academy of Management Journal; 61(6), 2343-66.

Papageorgiou A, Gianniou M, Wilson P, Moneta B, Bilello D, Clough J. (2019): The bright side of dark: Exploring the positive effect of narcissism on perceived stress through mental toughness. Personality and Individual Differences Journal; 139: 116-24.

Thulth A, Sayej S. (2015): Selected organizational factors affecting performance of professional nurses in North West bank governmental hospitals. Journal of Education and Practice; 6 (7): 23.

Wojciszke B, Abele E, Baryla W, (2009): Two dimensions of interpersonal attitudes: Liking depends on communion, respect depends on agency. European Journal of Social Psychology ; 39: 973-90. 


\section{الصلابه العقليه وحساسية الرفض و علاقتهم بالأداء المهني بين طاقم التمريض بوحده العناية المركزة و وحدات التمريض النفسي}

د/ سمر مبروك عبد السلام النحر اوي _ـد / مروة سمير سرور

مدرس تمريض الصحه النفسيه و العقليه_ كليه التمريض__ جامعه طنطا ، مدرس إداره الخدمات التمريضيهـ_ كليه

التمريض__جامعه طنطا

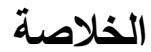

يقبل معظم طاقم التمريض الذين يعملون في وحدات العناية المركزة و الوحدات النفسيه المواهب و المهارات النفسية على أنها قوة عقلية وحساسية تجاه الرفض تؤثر على أداء عمهم. والهاف من الدراسه: تحديد الإرتباط بين الصلابة ولية العقلية وحساسية الرفض مع الأداء المهني بين طاقم التمريض بوحده العناية المركزة و وحدات التمريض النفسي. وأجريت هذه الدراسة علي طاقم التمريض في وحدة الباطنه بالعناية المركزة باعتبار ها المجموعة الأولى ووحدات التمريض النفسي الداخلي باعتبار ها المجموعة الثانية و عددهم مائه. أدوات جمع البيانات: تم استخدام ثلاث أدوات باتهات لتجميع البيانات لهذه الدراسة ، الأداة الأولى: استبيان الصلابه العقلية ، والأداة الثنانية: استبيان حساسية الرفض ، و والأداة الثالثة: استبيان لملاحظه الأداء المهني للتمريض. و قد أظهرت النتائج أن الغالبية (91.5\%) من المجموعة الثانية حصلت على مستوى منوسط من الصلابة العقلية وحساسية الرفض مقارنة بـ (54.7\% و 81.1\%) من المجموعة الأولى

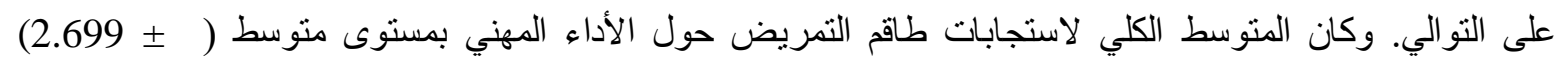
10.930 للمجموعة الأولى مقارنة بالمجموعة الثنانية متوسط (9.081 ـ 2.368) ـ و الخلاصة: لم يكن هناك ارتباط أو علاقه بين مستويات الصلابة العقلية وحساسية الرفض وبين مستويات الأداء المهني لطاقم التمريض الذي يعمل في وحدة العناية المركزة وطاقم التمريض الذي يعمل في وحدات التمريض النفسي.و لذلك نوصي بعمل برنامج تدريبي لطاقم التمريض في الوحدتين حول الصلابة العقلية وحساسية الرفض والحفاظ على التوجيه الدوري لطاقم التمريض حول أبعاد الأداء المهني.

الكلمات المرشده: وحدة العناية المركزة ، الصلابة العقلية ، وحدات التمريض النفسي، حساسية الرفض ، طاقم التمريض، الأداء المهني. 